UNDERGRADUATE RESEARCH IN NATURAL AND CLINICAL SCIENCE AND TECHNOLOGY (URNCST) JOURNAL Read more URNCST Journal articles and submit your own today at: https://www.urncst.com

\title{
Scinapse Undergraduate Science Case Competition: Cultivating the Minds of Future Researchers
}

Steven Chen [1]*, Saba Manzoor [2], Keerthana Pasumarthi [2], Mateen Noori [3], Cindy Zhang [2], Dominic Cyr [4], Jamie Ghossein [4], Céline Sayed [4]

[1] Undergraduate Medical (MD) Program, McMaster University, Hamilton, Ontario, Canada

[2] Bachelor of Health Sciences Program, McMaster University, Hamilton, Ontario, Canada

[3] Bachelor of Science Program, McMaster University, Hamilton, Ontario, Canada

[4] Undergraduate Medical (MD) Program, University of Ottawa, Ottawa, Ontario, Canada

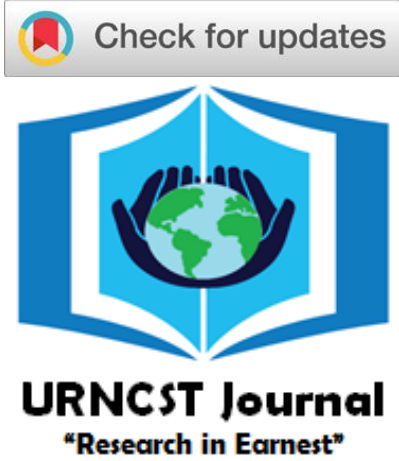

*Corresponding Author: steven.chen@medportal.ca

\begin{abstract}
The Scinapse Undergraduate Science Case Competition (USCC) is an annual provincial student initiative that was established in 2012. The organization was founded on the premise of bridging the gap between classroom knowledge and the practical application of student inquiry. Inspired by a "case-study" problem-based learning style, the USCC offers a mechanism to inspire student research at an undergraduate level, without typical barriers such as funding and lab equipment. This guest editorial serves to describe the layout for the organization as well as reflect on the challenges and strategies in hosting the annual competition.
\end{abstract}

Keywords: Student research; undergraduate research; case competition; problem-based learning; proposal development; scientific education

\section{Introduction}

Scinapse was founded in 2012 to address the gap between classroom learning and the practical applications of science. The founding group of students from the University of Western Ontario, in London, Ontario, Canada, came to realize that didactic, content-heavy lectures required a supplement to inspire a passion for the sciences. In order to translate classroom knowledge into ideas and critical thinking, these students launched the inaugural Scinapse Undergraduate Science Case Competition (USCC) [1].

The format of the competition was inspired by a "casestudy" problem-based learning style, which is often employed by business and medical schools [2,3]. For the USCC, these case studies were adapted with a twist; there was no correct answer. Instead of propelling students towards a single correct answer, the USCC was structured to encourage abstract and interdisciplinary thinking. Students would be encouraged to emulate the role of a real scientist consider a real-world issue, propose novel experiments and integrate current scientific trends and knowledge to propose a solution. With support from faculty and staff, the first ever USCC was funded by the University of Western Ontario and drew the attention of 300 students that participated within its first year [1].

In the following years, the competition grew to include additional universities across Ontario, Canada; the University of Toronto, Queen's University and McMaster University were among the first to participate, followed by Water- loo University, the University of Ottawa and York University. Each year, students were given a trending scientific issue (e.g. cystic fibrosis, food security, Zika virus) and encouraged to approach these prompts from the perspective of a scientist. The competition eventually evolved and became a registered non-profit organization that obtained funding from participating universities and external sponsors such as the Nelson and Pearson publishing groups. The case studies were published in the National Center for Case Study Teaching in Science annually, with top winners also gaining valuable research opportunities and the potential to publish their work in peer-reviewed journals [1].

Today, Scinapse's headquarters have transitioned to the University of Ottawa, which also plays host to the provincial finals of the USCC, where teams gather from across Ontario and other Canadian provinces. The original team of founders from the University of Western Ontario have moved on to careers in diverse areas of science: medical school, graduate school, and industry. The USCC's message to pursue science as a creative undertaking still stands strong and is integral to the mandate of Scinapse - to instill passion for research in parallel with promoting undergraduate scientific education [1].

\section{Details of the competition}

Registration for Scinapse USCC opens during the fall of each year and invites individuals from universities all across Ontario to participate. Students register in teams of 
UNDERGRADUATE RESEARCH IN NATURAL AND CLINICAL SCIENCE AND TECHNOLOGY (URNCST) JOURNAL Read more URNCST Journal articles and submit your own today at: https://www.urncst.com

2-4 and compete within Lower (1st and 2nd year undergraduates) or Upper Divisions (3rd year and above undergraduates). Following registration, participants are asked to tackle a unique scientific challenge, specifically chosen for the year's competition. Once the case is revealed, students have three weeks to complete a written proposal no longer than 1000 words targeting a specific aspect of the overarching issue. Judges from a variety of disciplines, mainly comprised of professors from partnering universities, are asked to evaluate these proposals on the basis of clarity, feasibility, and applicability [1].

In late-March, the top $10 \%$ of the highest scoring teams in both the Lower and Upper divisions from each university are invited to the University of Ottawa to attend a conference and compete in a final poster presentation round. This aspect of the competition is evaluated not only based on the quality of the scientific ideas, but also on the communication skills involved in pitching a research proposal. During this event, participants have a valuable opportunity to engage in several enriching workshops and interact with likeminded peers. The conference and competition is concluded with an awards ceremony during which Gold, Silver and Bronze medals are awarded to highest scoring teams in both the Lower and Upper level divisions [1].

\section{Role in Education}

The hope for students who participate in the USCC is that regardless of whether they win a medal, they will reap the many benefits through the values and experiences offered by Scinapse. The case competition serves as a mechanism for education by encouraging students to apply their skills towards a meaningful purpose of tackling a current issue. The competition evaluates proposals based on the understanding of the problem, pragmatism and depth of the solution. By focusing on these attributes, students are able to develop their research acuity and understanding of research methodology. Since each student reads and analyses a variety of articles to supplement their knowledge of the case topic, they have the opportunity to teach one another. Thus, students can not only learn from the literature, but also from their peers. Furthermore, they must familiarize themselves with solutions actively being used in the world to address the case issue. By identifying the challenges with current solutions, students can apply their knowledge and critical thinking to propose novel approaches. Students are able to go through many iterations through trial and error, and in doing so, they acquire a more accurate perspective of scientific research that cannot be attained in a traditional lecture setting. Following this unique experience, students can better understand research concepts, motivating them to pursue interests in specific branches of science. Moreover, the team-based approach of the USCC mirrors practical lab and industry settings, thereby fostering teamwork and small group cooperation skills for the real world.

At the end of the first round, teams draft a structured, meaningful project proposal for the case which also re- quires them to develop their scientific writing skills. This is all done in a safe microcosm without the fear of receiving an unsatisfactory grade or making costly mistakes in a lab environment-the factors that most frequently limit creativity in science.

The second round of the USCC focuses on building oral communication and presentation skills. Students are encouraged and supported with tools on how to make clear and impactful research posters. Teams that make it to the final round are judged by researchers on their ability to construct and deliver a concise oral pitch of their proposal. The final round also serves as a useful networking experience for teams to learn from others regarding different innovative ways of approaching the same problem.

\section{Challenges of organizing a provincial conference}

Organizing the USCC has proven to be a logistical challenge, with each round of the competition presenting its own sets of hurdles. Planning for the competition begins one year in advance, when a team of individuals is selected to organize the competition.

The USCC is unique given that the organizing team is split into 2 fronts: the provincial front, which is responsible for hosting the first and second round of the competition, as well as the regional front, consisting of one team from each participating university across the province. The regional committees are in charge of promotion, recruitment, and mentorship of their local participants, including hosting workshops and securing funding for travel expenses and poster printing for those who participate in the second round of the competition.

Given that the USCC organizing team is largely composed of undergraduate students, the summer months have proven to be the most useful in preparing the competition. During this time, judges are recruited, the case and promotional material are drafted, and a sponsorship package is assembled.

The sheer number of participants for the first round of the competition, often consisting of over 200 teams and 700 individual participants, requires structured communication and a clear division of tasks. An organizational chart is drafted in order for team members to understand their individual roles, and subcommittees acting as small task forces (a sub-committee for communications, for judging and scoring, for mentoring, etc). Each subcommittee has one designated lead with whom the president of Scinapse corresponds, in order for the latter to efficiently oversee all operations. Automation through the use of excel macros and purchased software has proven essential when sending emails, handling scores and distributing judges, since this significantly reduces the workload for individual team members.

Meetings requiring in-person attendance of all team members rarely occur, save for when everyone's participation is relevant, such as the selection of the case topic. Communication using online platforms like Facebook and 
UNDERGRADUATE RESEARCH IN NATURAL AND CLINICAL SCIENCE AND TECHNOLOGY (URNCST) JOURNAL Read more URNCST Journal articles and submit your own today at: https://www.urncst.com

email are preferred, as different class schedules pose a challenge to finding common availability for in-person meetings. However, each subcommittee communicates and meets on a more regular basis, and their leads relay important updates via bi-weekly or monthly reports to the president. These reports have been useful in overcoming challenges in communication, and they ensure efficient follow-up of all tasks completed.

For the final round of the USCC, support from the host university is essential for funding and securing a venue on campus. Meetings with the deans of the faculties of Science and Medicine are held at the beginning of the academic year in order to discuss financial sponsorship, which supplements the revenue generated from participant registration. Their support is vital to cover the essential costs of organizing both rounds of the USCC such as fees for hotels, food, AV, and space rental. Since any additional sponsorship funding will vary from year to year, it is reserved for non-essential costs that enhance the experience of the participants, which include prizes for winners and finalists, organization of a social, etc.

In summary, a precise organizational structure, timely follow-up through regular reporting, early preparation and the use of automation has allowed the Scinapse USCC to operate efficiently for many consecutive years.

Through the efforts of many passionate students from across Ontario, the Scinapse USCC has successfully provided undergraduate science students with opportunities to explore research, further develop important skills and explore the world of science through applied learning. With the experience participants acquire through the successful completion of the competition, Scinapse aims to foster interest and ingenuity in future researchers and ultimately contribute to the advance of science.

\section{List of Abbreviations}

USCC: Undergraduate Science Case Competition

URNCST: Undergraduate Research in Natural and Clinical Science and Technology

\section{Conflicts of Interest}

The author(s) declare that they have no conflicts of interest.

\section{Ethics Approval and/or Participant Consent}

Not applicable.

\section{Authors' Contributions}

All authors made contributions to the design of the study, drafted the manuscript, and provided final approval of the version to be published. The authors are members of the Scinapse USCC executive team, and wrote this article in collaboration with the URNCST Journal.

\section{Acknowledgements}

The authors are appreciative of the interview response provided by Charlie Zhao, one of the initial founders of Scinapse. Charlie's response helped to inform the section on the 'History of Scinapse'.

The Scinapse provincial team would like to thank the URNCST Journal for supporting the publication of the 2017/2018 abstract booklet. We look forward to continuing our collaboration with URNCST Journal which has had a positive impact on the participants of the Undergraduate Science Case Competition.

\section{Funding}

This study was not funded.

\section{References}

[1] USCC [Internet]. S C I N A P S E. [cited 2019 Feb 19]. Available from: http://scinapsescience.com/uscc/

[2] Savery JR, Duffy TM. Problem based learning: An instructional model and its constructivist framework. Educational technology. 1995 Sep 1;35(5):31-8.

[3] Barrows HS. A taxonomy of problem-based learning methods. Medical education. 1986 Nov;20(6):481-6. https://doi.org/10.1111/j.1365-2923.1986.tb01386.x

\section{Article Information}

Managing Editor: Jeremy Y. Ng

Article Dates: Received Feb 02 13; Published Apr 0219

\section{Citation}

Please cite this article as follows:

Chen S, Manzoor S, Pasumarthi K, Noori M, Zhang C, Cyr D, Ghossein J, Sayed C. Scinapse Undergraduate Science Case Competition: Cultivating the minds of future researchers. URNCST Journal. 2019 Apr 02: 3(4).

https://urncst.com/index.php/urncst/article/view/136

DOI Link: https://doi.org/10.26685/urncst.136

\section{Copyright}

(C) Steven Chen, Saba Manzoor, Keerthana Pasumarthi, Mateen Noori, Cindy Zhang, Dominic Cyr, Jamie Ghossein, Céline Sayed (2019). Published first in the Undergraduate Research in Natural and Clinical Science and Technology (URNCST) Journal. This is an open access article distributed under the terms of the Creative Commons Attribution License 
UNDERGRADUATE RESEARCH IN NATURAL AND CLINICAL SCIENCE AND TECHNOLOGY (URNCST) JOURNAL

Read more URNCST Journal articles and submit your own today at: https://www.urncst.com

(https://creativecommons.org/licenses/by/4.0/), which permits unrestricted use, distribution, and reproduction in any medium, provided the original work, first published in the Undergraduate Research in Natural and Clinical Science and Technology

(URNCST) Journal, is properly cited. The complete bibliographic information, a link to the original publication on

http://www.urncst.com, as well as this copyright and license information must be included.
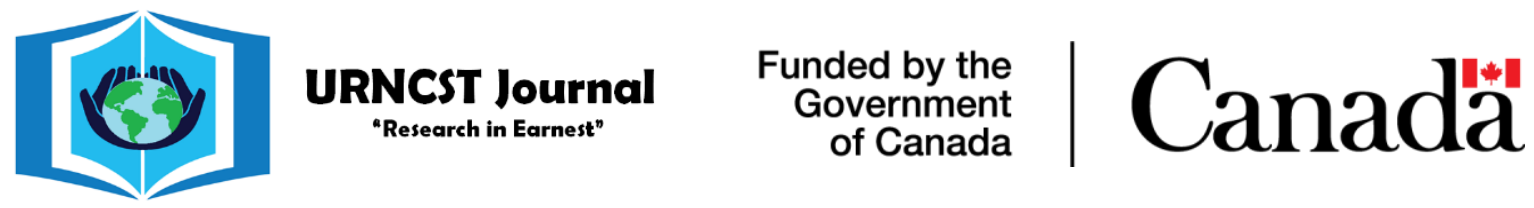

Do you research in earnest? Submit your next undergraduate research article to the URNCST Journal!

| Open Access | Peer-Reviewed | Rapid Turnaround Time | International |

| Broad and Multidisciplinary | Indexed | Innovative | Social Media Promoted |

Pre-submission inquiries? Send us an email at info@urncst.com | Facebook, Twitter and LinkedIn: @URNCST

Submit YOUR manuscript today at https://www.urncst.com! 